\title{
Students' Mathematical Connection Skills Reviewed from Learning Styles
}

\author{
Ujang Suprianto (*), Heni Pujiastuti \\ UNTIRTA, Jalan Raya Jakarta Km.4 Pakupatan Serang, Indonesia
}

\begin{abstract}
Received: December 31, 2019 The purpose of this study is to determine the distribution of student Revised: March 03, 2020 learning styles, to determine the average mathematical communication Accepted: March 04, 2020 skills that have auditory, visual, and kinesthetic learning styles. and to find out if there are significant differences in the ability of mathematical connections between students who have auditory, visual, and kinesthetic learning styles. This research was conducted at Public Senior High School 17 Pandeglang in class XII MIPA. The instrument used was in the form of a learning style questionnaire and a test of mathematical connection abilities. This type of research is a comparative study with a quantitative approach. Based on the results of data processing, that the distribution of student learning styles is included in the Auditory learning style of $34 \%$ of students, visual $46 \%$ of students, and kinesthetic $19 \%$ of students. By using a scale of $0-50$, the average mathematical connection ability of students is 29.58, whereas when viewed from each distribution of learning styles, the average mathematical ability of auditory students is 24.89 , visual students 28.33, and kinesthetic students 34,40 . Based on the results of the analysis with the ANOVA test and t-test (Dunnet) that there is a significant difference in the ability of students' mathematical connections between auditory, visual and kinesthetic learning styles with a significant level of $\alpha=0.05$, and the results of the value of $F_{\text {count }}>F_{\text {table }}=3.62>3,42$, where the kinesthetic learning style has higher mathematical connection ability than auditory and visual learning styles.

Keywords: Learning Style, Math connection ability
\end{abstract}

(*) Corresponding Author: $\quad$ ujsuprianto17@gmail.com, 083812915118

How to Cite: Suprianto, U. \& Pujiastuti, H. (2020). Students' mathematical connection skills reviewed from learning styles. Formatif: Jurnal Ilmiah Pendidikan MIPA, 10 (1): 47-56. http://dx.doi.org/10.30998/formatif.v10i1.5474

\section{INTRODUCTION}

Mathematics is one of the subjects that has an important role in developing students' mathematical abilities. This is in line with the learning objectives of mathematics formulated by the National Council of Mathematics Teachers (NCTM), namely learning to communicate (mathematical communication), reasoning (mathematical reasoning), solving problems (mathematical problem solving), learning to link ideas (mathematical connections), Learn to present ideas (mathematical representation). Based on the objectives of mathematics learning, it can be concluded that mathematics learning can help students understand concepts, solve systematic problems, associate mathematics with everyday life and can express mathematical ideas both verbally and in writing (Muhamad, 2013).

The ability to explain the interrelationships between concepts is part of the ability of mathematical connections (Kaur \& Toh, 2012). Calling mathematical connections is as the ability to see and connect mathematical ideas, between mathematics and other subjects, or between mathematics and everyday life. According to Coxford (Aspuri, 
2019), they argue that the ability of mathematical connections includes: (1) connecting the ability of conceptual and procedural knowledge, (2) using mathematics on other topics (other curriculum areas), (3) using mathematics in life activities, (4) ) see mathematics as one integrated entity, (5) apply mathematical thinking skills and make models in solving problems in other subjects, (6) find connections between mathematical topics, and (7) recognize various representations for the same concepts. In the ability of mathematical connections possessed by these students, where students must be able to solve a mathematical concept that connects mathematical concepts with other subject areas.

As a consequence, students can have not only the ability in mathematical concepts but also master the concepts of other subjects as well. The ability of students to solve mathematical problems is certainly very different according to their respective styles, this is influenced because each student has a different learning style. Learning style is a combination of how a person absorbs, organizes and processes information (De Porter \& Hernacki, 2002). Dunn \& Dunn explained that learning styles are a collection of personal characteristics that make learning effective for some people and ineffective for others. Learning style is a consistent way carried out by a student in capturing stimulus or information, how to remember, think, and solve problems (Fatkhiyyah, Winarso, \& Benefits, 2019). Accordingly, the learning style is a consistent method used by someone in the process of thinking to capture, organize, and to process the information received.

According to De Porter \& Hernacki, 2007, there are three learning styles of a person, namely visual, auditory, and kinesthetic learning styles. Basically, each student uses these three learning styles, but most students are more inclined to one of these learning styles (Purbaningrum, 2017). Visual Learning Style -Eyes/visual aids- play an important role in the thinking process of students in this visual learning style, they learn through everything that can be seen. They think of using pictures in their brain and learn faster by using visual displays, such as diagrams, picture books, and videos. They take very detailed notes to get all information, need a holistic view and purpose, and be alert before mentally feeling confident about an issue or project. The visual learning style indicators are (a) learning by visual means, (b) understanding well about position, shapes, numbers, and colors, (c) neat and orderly, (d) uninterrupted by noise, and (e) difficult to accept verbal instructions.

Auditory Learning Style -Ear/hearing devices- play an important role in the thinking process of students in this auditory learning style, they learn through everything that can be heard. Students can learn quickly through verbal discussion and listen to everything that is said. They can digest well the information conveyed through voice tone, pitch (high and low), speed of speech and other auditory matters. Written information is sometimes difficult for students to receive in this auditory learning style. Students who like this can usually memorize faster by reading text or listening to sound. The auditory learning style indicators are (a) learning by listening, (b) both in oral activity, (c) having sensitivity to music, (d) easily distracted by noise, and (e) weak in visual activity.

The Kinesthetic Learning Style -Students with kinesthetic learning styles- learn through moving, touching, and doing. Kinesthetic students cannot stand to sit for long listening to lessons but they are better if the learning process is accompanied by physical activities. Kinesthetic learning styles -students speak slowly- respond to physical attention, touch people to get their attention, stand close when talking to people. They learn through manipulation and practice, memorizing by walking and seeing, using fingers as a pointer when reading, using lots of body cues, using words that contain action, like books that are plot oriented. The kinesthetic learning style indicators are (a) learning with physical activity, (b) sensitive to expressions and body language, (c) 
oriented to the physical and moving a lot, (d) like to try and not tidy, (e) Weak in a verbal activity.

With this difference in learning styles, there is the potential for differences in or not the mathematical connection ability of students in the learning styles possessed by each student. Therefore, the researchers in this study aimed to determine the existence of significant differences in the ability of students' mathematical connections in terms of auditory, visual and kinesthetic learning styles possessed by students in class XII MIPA Public Senior High School 17 Pandeglang.

\section{METHODS}

This type of research used in this study was a comparative study with a quantitative approach. This study was chosen because of its suitability with the research objectives namely to distinguish the magnitude of students' mathematical connection abilities based on auditory, visual and kinesthetic learning styles. The comparative study (comparative causal) is a kind of descriptive research by identifying causal relationships and identifying differences in some variables with independent variables not manipulated or controlled (Anggito \& Setiawan, 2018).

This research used the "Expost-Facto" research design which is a study that does not control its independent variables. According to Siregar (2014), expost-facto research is a research conducted empirically and systematically with researchers not exercising direct control over their independent variables or their independent variables not manipulated (Fatkhiyyah et al., 2019).

The population in this study was divided into two types. The two types were the target population and the affordable population. The target population in this study was all students of Public Senior High School 17 Pandeglang. Meanwhile, the outreach population was class XII of Public Senior High School 17 Pandeglang consisting of 3 classes. The research sample in this study used a purposive sampling technique. Purposive sampling is a way to determine respondents who will be sampled based on certain criteria (Tongco, 2007).

The results of these considerations obtained research samples namely class XII MIPA Public Senior High School 17 Pandeglang. There were two types of data collection techniques in this study. The first was learning style tests (Rose \& Tracy, 1998). Whereas the second one was using a math connection ability test. The data collection techniques can be presented in table 1 below.

Table. 1 Instrument Data Collection Techniques

\begin{tabular}{cccc}
\hline Data & Data collection technique & Instrument & $\begin{array}{c}\text { Data } \\
\text { source }\end{array}$ \\
\hline $\begin{array}{c}\text { Student Learning } \\
\text { Styles }\end{array}$ & Inventory & $\begin{array}{c}\text { Questionnaire } \\
\text { (36 Questions) }\end{array}$ & Student \\
$\begin{array}{c}\text { Mathematical } \\
\text { Connection } \\
\text { Ability }\end{array}$ & Test & 5 Item & Student \\
\hline
\end{tabular}

Reference in grouping the average ability of students' mathematical connections with criteria on a scale of 0-50 with the interpretation as follows. 
Table 2. Mathematical Connection Ability Scale

Average Mathematics

Connection Capabilities of Interpretation

Students

\begin{tabular}{rc}
\hline $0-16,6$ & Low \\
$0,16,7-33,3$ & Mid \\
$33,34-50$ & High \\
\hline
\end{tabular}

The data analysis technique used to determine students' mathematical connection abilities and student learning styles was a descriptive statistical analysis (Muhson, 2006). Meanwhile, to find out differences in the average ability of students' mathematical connections in terms of differences in student learning styles, it was using inferential statistical analysis namely ANOVA statistical analysis and t-test (Dunnet) (Markowitz, 2018).

\section{RESULTS \& DISCUSSION}

\section{Results}

Student learning styles can be known from the results of the questionnaire distributed to students, the questionnaire can distinguish student learning styles consisting of auditory, visual and kinesthetic learning styles The three learning styles can be measured from the dimensions of student learning styles which include learning to rely on feelings, group learning, being open to others, learning from observations, intensive listening to meaning, learning in various ways, being careful in learning, thinking logically, behaving according to theory, making preparations before learning, loving those of an analytical nature, completing tasks independently, active in learning, learning through practice, and carrying out tasks in accordance with the provisions. As for after collecting research data by distributing questionnaire instruments to students, the following types of learning styles are obtained:

Table 3. Distribution of types of student learning styles

\begin{tabular}{ccccc}
\hline $\begin{array}{c}\text { Type of Learning } \\
\text { Style }\end{array}$ & Auditory & Visual & Kinesthetic & Total \\
\hline Total students & 9 & 12 & 5 & 26 \\
Percentage & $34 \%$ & $46 \%$ & $19 \%$ & $100 \%$ \\
\hline
\end{tabular}

Based on table 3, it was found that the type of learning style owned by students of class XII MIPA Public Senior High School 17 Pandeglang with the number of 26 students is the type of auditory learning style by 9 students with a percentage of $34 \%$, visual type by 12 students with a percentage of $46 \%$ and the kinesthetic type by 5 students with a percentage of $19 \%$.

Students' mathematical connection abilities are measured through the ability to connect their conceptual and procedural knowledge abilities, use mathematics in other topics (other curriculum areas), use mathematics in life activities, view mathematics as an 
integrated whole, apply mathematical thinking skills and make models in solving problems in another lesson, knowing the connections between mathematical topics and knowing various representations for the same concept. The descriptive statistical research results of students' mathematical connection ability were obtained from the results of the test items as many as 5 items distributed to students of class XII MIPA Public Senior High School 17 Pandeglang as many as 26 students as shown in table 4 below.

Table 4. Descriptive Data Results of Mathematical Connection capabilities

\begin{tabular}{cccc}
\hline $\begin{array}{c}\text { Learning } \\
\text { Style }\end{array}$ & $\mathrm{N}$ & Mean & Std. Deviation \\
\hline Auditory & 9 & 24.89 & 3.62 \\
Visual & 12 & 28.33 & 7.51 \\
Kinesthetic & 5 & 34.40 & 7.92 \\
\hline Total & 26 & 29.21 & 2.37 \\
\hline
\end{tabular}

It can be seen that the total research sample of 26 students of class XII MIPA in Public Senior High School 17 Pandeglang obtained an average value (mean) mathematical connection ability of the auditory type students is 24.89 , the standard deviation of 3.62. The visual type obtained an average value of 28.33 standard deviations of 7.51 and the kinesthetic type obtained an average value of 34.40, a standard deviation of 7.92. Meanwhile, the overall average value is 29.21 and the standard deviation is 2.37 . After the data are known to be normally distributed and have the same variant (homogeneous), ANOVA test is then performed. ANOVA test was conducted to determine whether or not there were differences in the ability of students' mathematical connections in terms of auditory, visual and kinesthetic learning styles.

Table. 5 One Way ANOVA Test Results

\begin{tabular}{cccccc}
\hline $\begin{array}{c}\text { Source of } \\
\text { Variance }\end{array}$ & JK & dk & RJK & Fhit & Ftab \\
\hline Between groups & 307.96 & 2 & 153.98 & 3.62 & 3.42 \\
In Group & 977.01 & 23 & 42.48 & & \\
\hline Total & 1284.96 & 25 & & & \\
\hline
\end{tabular}

Based on table 5, values obtained $F_{\text {count }}>F_{\text {table }}=3.62>3.42$, meaning that there are significant differences in the ability of students' mathematical connections between auditory, visual, and kinesthetic learning styles. If based on significance then (sig) $<\alpha$ is $0.00<0.05$ which means the same, namely there are significant differences in the ability of students' mathematical connections between auditory, visual and kinesthetic learning styles. The kinesthetic learning style obtains an average score of higher mathematics ability than the auditory and visual learning styles, while the results of the value of the mathematics connection ability of the visual learning style are higher compared to students who have an auditory learning style. Thus, there are differences in the ability of mathematical connections in terms of student learning styles. As for knowing the influence of learning styles on the ability of mathematical connections, students can use the statistical test t-test (Dunnet), after the calculation is obtained the following data: 
Table 6. Data Calculation Results t Test (Dunnet)

\begin{tabular}{cccl}
\hline $\mathrm{t}$ - test on Learning Style & $\mathrm{t}$-count value & $\begin{array}{c}\text { T-table value } \\
\text { (level 0.05) }\end{array}$ & Information \\
\hline $\mathrm{t}-(\mathrm{A}-\mathrm{V})$ & 1.19 & 1.7 & $\mathrm{~A}=$ auditory \\
$\mathrm{t}-(\mathrm{A}-\mathrm{K})$ & 2.61 & & $\mathrm{~V}=$ Visual \\
$\mathrm{t}-(\mathrm{V}-\mathrm{K})$ & 1.74 & & $\mathrm{~K}=$ Kinesthetic \\
\hline
\end{tabular}

In table 6. above, obtained t-count on auditory learning styles with visual learning styles with $\mathrm{t}-(\mathrm{AV})<\mathrm{t}$-table $=1.19<1.7$, at the level of $\mathrm{a}=0.05$ illustrates that significantly the mathematical connection ability of learning styles visual is not higher than auditory learning style, while for t-count auditory and kinesthetic learning styles, obtained $\mathrm{t}-(\mathrm{A}-\mathrm{K})>\mathrm{t}$-table $=2.61>1.7$ at the level $\mathrm{a}=0.05$, illustrating that significantly the ability of connections mathematics in kinesthetic learning styles is higher than auditory learning styles, whereas in t-calculate visual and kinesthetic learning styles t- (V $-\mathrm{K})>\mathrm{t}$-table $=1.74>1.70$ at the level $\mathrm{a}=0.05$, also illustrates that significantly the ability of mathematical connections in kinesthetic learning styles is slightly higher than in visual learning styles.

\section{Discussion}

In general, students are the most preferred and favorite visual learning styles. Maybe the visual learning style is easier for students, more interesting, and less power is needed. Based on the learning style questionnaire test distributed to students of class XII MIPA Public Senior High School 17 Pandeglang. The distribution of auditory learning style students was 9 students at $34 \%$. While the visual learning styles were 12 students by $46 \%$ and the kinesthetic type were 5 students by $19 \%$. Based on the data distribution, most students have a visual learning style, they learn through everything that can be seen. They think of using pictures in their brain and learn faster by using visual displays, such as diagrams, picture books, and videos. They take very detailed notes to get all information, need a holistic view and purpose and be alert before mentally feeling confident about an issue or project.

This finding seems to be similar as a study conducted by Frankel A (2009) who reported that visual, auditory, and kinesthetic learning styles revealed 54.0\%, 26.9\%, and $19.1 \%$ respectively. Also, the results of this disagreement with Rajshree S. (2013) study, which were carried out in secondary school student schools. Visual, auditory, and kinesthetic learning styles were observed as (33.5\%), (28.5\%), and (38.0\%) respectively. Jugastudi Leslie (2007) showed that learning styles among adult students were (34\%) participants had visual preferences, 34\% had hearing, 23\% had kinesthetic, and 9\% had multimodal learning preferences, and were preferred by students who younger kinesthetic learning styles are more than adult learners (Ibrahim \& Hussein, 2015).

Each student has a different learning style. For this reason, in conveying subject matter, in this case, mathematics requires creativity of a teacher in order to create a fun teaching for all students. In addition to the data above, there are other data that support this assumption, namely the acquisition of an average score of students' mathematical connection ability scores. Based on the data obtained from the results of the mathematics connection ability test it can be seen that the group of students who have kinesthetic learning styles get an average score of 34.40 while the group of students who have a visual learning style only get a final score of 28.33 and groups of students who have 
having an auditory learning style gained an average score of 24.89. Based on the data above, the conclusions obtained through empirical statistical analysis prove that there are differences between the three groups of students who have visual, auditory and kinesthetic learning styles.

The highest mathematical connection ability of students is in students who have kinesthetic learning styles because students who have kinesthetic learning styles have kinesthetic learning through moving, touching, and doing. This is in line with previous studies conducted by Leny Hartati that kinesthetic abilities have higher abilities compared to other learning styles (Hartati, 2015).

In the study (Liew, Sidhu, \& Barua, 2015), it was also explained that out of 343 students $(81.9 \%)$ had unimodal learning styles, while 76 others $(18.1 \%)$ used multimodal learning styles. Among unimodal students, namely auditory, visual and majority learning styles $(30.1 \%)$ are Kinesthetic (K) types. Among the medium and high achievers on summative exams, the majority had a kinesthetic learning style $(30.5 \%)$ and also strategic / in-depth learners (79.4\%). Although learning styles and approaches do not significantly contribute to learning outcomes in summative exams, there are differences in summative exam results.

Each student has their own learning style, namely auditory, visual, and kinesthetic (De Porter \& Hernacki, 2007). Each learning style has its own singularity and if students know their learning styles well, they will get good results. The results of the analysis show that there are differences in students' mathematical connection abilities between auditory, visual, and kinesthetic learning styles. This is based on the $F_{\text {count }}$ value of 3.62 which is greater than the $F_{\text {table }}$ value of 3.42. This is in line with the results of research by Weiss, Kramarski and Talis (2006) that students' mathematical connection abilities differ by group learning styles.

The average mathematical connection ability of students with kinesthetic learning style type has a difference with the average mathematical connection ability of students with auditory and visual learning style types. Every student with a certain learning style has a different mathematical connection ability than students who belong to other learning styles, this happens because each type of learning style has its own way of learning that is the type of auditory learning style students learn through everything that can be heard, the type of learning style visual students' thought processes, they learn through everything that can be seen and the types of learning styles kinesthetic learning through moving, touching, and doing.

Based on the results of data processing in class XII MIPA Public Senior High School 17 Pandeglang, the distribution of student learning styles is included in the auditory learning styles of $34 \%$ students, Visual $46 \%$ students, and Kinesthetic $19 \%$ students. By using a scale of $0-50$, the average mathematical connection ability of students is 29.58 , whereas when viewed from each distribution of learning styles, the average mathematical ability of auditory students is 24.89 , visual students 28.33 , and kinesthetic students 34, 40. And based on the results of the analysis with the ANOVA test and t-test (Dunnet), there are significant differences in students' mathematical connection abilities between auditory, visual and kinesthetic learning styles with a significant level of $\alpha=0.05$, and the results of the value of $F_{\text {count }}>F_{\text {table }}=3.62>3.42$, where the kinesthetic learning style has higher mathematical connection abilities than the auditory and visual learning styles. 


\section{CONCLUSION}

Distribution of student learning styles in class XII MIPA Public Senior High School 17 Pandeglang is diverse and evenly distributed, with the most types of visual learning styles by $46 \%$. The average ability of students' mathematical connections by seeing and connecting mathematical ideas, between mathematics and other subjects, or between mathematics and daily life, can be categorized as average. The average written mathematical ability of students based on learning styles is different. The highest average mathematical connection ability of students comes from kinesthetic learning style groups. The visual learning style group has an average mathematical connection ability which is moderate and the lowest one comes from the auditory learning style group. The results of the analysis show that there are significant differences between students' mathematical connection abilities based on differences in auditory, visual and kinesthetic learning styles, with a significant level $\alpha=0.05$. These results indicate the average ability of students' mathematical connections in each learning style has a significant difference between learning styles with other learning styles.

\section{REFERENCES}

Anggito \& Setiawan. (2018). Metedologi Penelitian Kualitatif. Sukabumi: CV Jejak.

Aspuri, A. (2019). Kemampuan koneksi matematis siswa SMP dalam menyelesaikan soal cerita: Studi Kasus di SMP Negeri 3 Cibadak. JIPM (Jurnal Ilmiah Pendidikan Matematika), 7(2), 124. https://doi.org/10.25273/jipm.v7i2.3651

Azizah, M., \& Fauziyah, F. (2019). Pengaruh kemampuan koneksi matematika terhadap hasil belajar siswa pada materi garis singgung lingkaran kelas VIII SMPN 2 Sumbergempol Tulungagung. Jurnal Pendidikan Matematika RAFA, 5(1), 1-9. https://doi.org/10.19109/jpmrafa.v5i1.2106

Baki, A., Kosa, T., \& Guven, B. (2011). A comparative study of the effects of using dynamic geometry software and physical manipulatives on the spatial visualisation skills of pre-service mathematics teachers. British Journal of Educational Technology, 42(2), 291-310. https://doi.org/10.1111/j.1467-8535.2009.01012.x

De Porter \& Hernacki. (2007). Quantum learning. Bandung: Mizan Media Utama.

Fatkhiyyah, I., Winarso, W., \& Manfaat, B. (2019). Kemampuan komunikasi matematika siswa ditinjau dari perbedaan gaya belajar menurut David Kolb. Jurnal Elemen, 5(2), 93. https://doi.org/10.29408/jel.v5i2.928

Hadin, Pauji, H. M., \& Arifin, U. (2018). Analisis kemampuan koneksi matematik siswa MTS ditinjau dari self regulated learning. JPMI Jurnal Pembelajaran Matematika Inovatif, 1(4), 657-666. https://doi.org/10.1007/978-3-8274-2352-8 21

Harie, S. (2015). Pengaruh metode pembelajaran dan gaya belajar terhadap kemampuan berpikir kritik biologi. Formatif: Jurnal Ilmiah Pendidikan MIPA, 5(3), 257-267. https://doi.org/10.30998/formatif.v5i3.651

Hartati, L. (2013). Pengaruh gaya belajar dan sikap siswa pada pelajaran matematika terhadap hasil belajar matematika. Formatif: Jurnal Ilmiah Pendidikan MIPA, 3(3), 224-235. https://doi.org/10.30998/formatif.v3i3.128

Ibrahim, R.A. \& Hussein, D. A. (2015). Assessment of visual, auditory, and kinesthetic learning style among undergraduate nursing students. International Journal of Advanced Nursing Studies, 5(1), 1. https://doi.org/10.14419/ijans.v5i1.5124

Ihat, S. (2019). Profile of student's mathematical connection abilities based on mathematical learning style and personality type. Formatif: Jurnal Ilmiah Pendidikan MIPA, 9(1), 45-58. https://doi.org/10.30998/formatif.v9i1.3119 
Indrawati, I. A. G. B. P. D. dan K. R. (2014). Perilaku mencatat dan kemampuan memori pada proses belajar Ida Ayu Gede Bintang Praba Dewi dan Komang Rahayu Indrawati. Jurnal Psikologi Udayana, 1(2), 241-250.

Kaur, B \& Toh, T. L. (2012). Reasoning, communication and connections in a-level mathematics. World Scientific, 127-147. https://doi.org/10.1142/9789814405430 0007

Kurnia, R. D. M., Mulyani, I., Rohaeti, E. E., \& Fitrianna, A. Y. (2018). Hubungan antara kemandirian belajar dan self efficacy terhadap kemampuan komunikasi matematis siswa SMK. JIPMat, 3(1), 59-64. https://doi.org/10.26877/jipmat.v3i1.2183

Laksono, R. D., \& Yuniarti, A. P. (2019). Mathematics learning achievement with snowball throwing for kinestetic learning style students. Formatif: Jurnal Ilmiah Pendidikan MIPA, 9(1), 23-32. https://doi.org/10.30998/formatif.v9i1.2849

Liew, S. C., Sidhu, J., \& Barua, A. (2015). The relationship between learning preferences styles and approaches) and learning outcomes among pre-clinical undergraduate edical students Approaches to teaching and learning. BMC Medical Education, 15(1), 1-7. https://doi.org/10.1186/s12909-015-0327-0

Markowitz, J. S. (2018). Multivariate analysis. SpringerBriefs in Public Health, (9783319772028), 71-81. https://doi.org/10.1007/978-3-319-77203-5_8

Muhamad, N. (2013). Pengaruh metode discovery learning untuk meningkatkan representasi matematis dan percaya diri siswa. Jurnal Pendidikan Universitas Garut, 09(01), 9-22.

Muhson, A. (2006). Teknik Analisis Kuantitatif. Makalah Teknik Analisis II, 1-7. Retrieved from http://staffnew.uny.ac.id/upload/132232818/pendidikan/Analisis+Kuantitatif.pdf

Papilaya, J. O., \& Huliselan, N. (2016). Identifikasi gaya belajar mahasiswa. Jurnal Psikologi Undip, 15(1), 56. https://doi.org/10.14710/jpu.15.1.56-63

Permana, A. (2016). Pengaruh gaya belajar dan motivasi belajar mahasiswa terhadap kemampuan belajar ilmu alamiah dasar. Formatif: Jurnal Ilmiah Pendidikan MIPA, 6(3), 276-283. https://doi.org/10.30998/formatif.v6i3.999

Purbaningrum, K. A. (2017). Kemampuan berpikir tingkat tinggi siswa smp dalam pemecahan masalah matematika ditinjau dari gaya belajar. Jurnal Penelitian Dan $\begin{array}{lll}\text { Pembelajaran } \quad \text { Matematika, } & \text { 10(2), }\end{array}$ https://doi.org/10.30870/jppm.v10i2.2029

Ramlah, Firmansyah, D., \& Zubair, H. (2014). Pengaruh gaya belajar dan keaktifan siswa terhadap prestasi belajar matematika (survey pada SMP negeri di kecamatan Klari kabupaten Karawang). Jurnal Ilmiah Solusi, 1(3), 68-75.

Schur, M. (1969). The background of freud's "disturbance" on the Acropolis. American Imago, 26(4), 303-323.

Sirait, E. D. (2017). Pengaruh gaya dan kesiapan belajar terhadap pemahaman konsep matematika siswa. Formatif: Jurnal Ilmiah Pendidikan MIPA, 7(3), 207-218. https://doi.org/10.30998/formatif.v7i3.2231

Sundayana, R. (2018). Kaitan antara gaya belajar, kemandirian belajar, dan kemampuan pemecahan masalah siswa SMP dalam pelajaran matematika. Mosharafa: Jurnal Pendidikan Matematika, 5(2), 75-84. https://doi.org/10.31980/mosharafa.v5i2.262

Tongco, M. D. C. (2007). Purposive sampling as a tool for informant selection. ethnobotany research and applications. Ethnobotany Research and Applications, 5, 147-158. https://doi.org/10.17348/era.5.0.147-158

Vanhelst, J., Béghin, L., Drumez, E., Baudelet, J. B., Labreuche, J., Chapelot, D., ... Ulmer, Z. (2016). Physical fitness levels in French adolescents: The BOUGE program. Revue d'Epidemiologie et de Sante Publique, 64(4), 219-228. https://doi.org/10.1016/j.respe.2016.05.002 
Weiss, I., Kramarski, B., \& Talis, S. (2006). Effects of multimedia environments on kindergarten children's mathematical achievements and style of learning. Educational Media International, 43(1), 3-17. https://doi.org/10.1080/09523980500490513

Widyawati, S. (2016). Pengaruh kemampuan koneksi matematis siswa terhadap prestasi belajar matematika ditinjau dari gaya belajar pada materi bangun ruang sisi datar siswa kelas IX SMP di kota Metro. Jurnal Iqra': Kajian Ilmu Pendidikan, 1(1), 4767. 